\title{
Relationship between food consumption, nutritional status and school performance
}

Open acess

${ }^{1}$ Universidade do Vale do Taquari (UNIVATES) - Lajeado (RS), Brazil. ¿Universidade Federal de Ciências da Saúde de Porto Alegre (UFCSPA) - Porto Alegre (RS), Brazil.

Corresponding author: simararufatto@terra.com.br Manuscript received: July 2018 Manuscript accepted: October 2018 Version of record online: November 2018

\section{Aline Lúcia Schmidt ${ }^{1}$, Maína Hemann Strack ${ }^{2}$, Simara Rufatto} Conde $^{1}$

\author{
Abstract \\ Introduction: Adequate feeding during childhood and \\ adolescence is extremely important, due to its act directly \\ on physical and cognitive development.
}

Objective: To verify the relationship between dietary intake and nutritional status with school performance.

Methods: It is an observational, quantitative and crosssectional study of 134 students aged 9 to 11 years. The nutritional status was measured using the Body Mass Index by age and gender, and food consumption was assessed through the 3-day Dietary Recall. For the knowledge of the school performance, the report cards of 2016 were consulted. A questionnaire was used to collect data regarding the marital status.

Results: Regarding nutritional status, $59,7 \%$ of the students presented eutrophy, $18,7 \%$ overweight, $15,6 \%$ obesity and $6,0 \%$ underweight. The consumption of calcium $(p<0,001)$ and iron $(p<0,001)$ were significantly below the values recommended by the Dietary Reference Intakes. Obese children consumed significantly more lipids $(p=0,026)$ and calories $(p=0,003)$ than the other students. The participation of ultra processed foods represented $35.50 \%$ of the total energy value, with a positive correlation between their consumption and the amount of calories consumed $(p=0,022)$ and inverse correlation with zinc intake $(p=0,007)$.

Conclusion: There was no significant association between dietary intake and nutritional status with school performance, but it was found that the marital status of the parents was associated with student performance, the children of married parents had a higher educational achievement than the children of separated parents.

Keywords: food consumption, nutritional status, nutritional deficiencies. 


\section{INTRODUCTION}

Child feeding has lately arisen great interest among researchers. Since this stage of life is a period of growth and formation of alimentary habits. Adequate nutrition during this period of life guarantees physical growth and mental development, while serves as a preventive factor for some diseases ${ }^{1}$.

The context in which a child is inserted influences eating habits, mainly through the availability of food at home, as well as stipulated rules for eating practices. In addition, parents tend to have their feeding behavior shown in their chidren, and a child who is exposed to inadequate food can follow it during adult life $\mathrm{e}^{2,3}$.

From the age of 10 the transition to adolescence begins, this period is characterized by intense changes of growth and development in a short period of time, nutritional status during this phase is extremely important, especially because it is a time with increased nutritional needs ${ }^{4}$.

Brazil is facing a defining moment of nutritional transition, in which the overweight and obesity prevalence exceeds malnutrition ${ }^{5}$, and food consumption is based on a great intake of foods high in fat and sugar and poor in nutrients ${ }^{6,7}$. Changes in the nutritional profile reveal a low quality of children and adolescents feeding, often exceeding the recommended energy sport, but with nutritional deficiencies in terms of micronutrients. Among the inadequacies of food consumption, iron and zinc deficiency are more prominent ${ }^{2}$. Eating habits are directly related to nutritional status and to the linear growth of children and adolescents in school age ${ }^{8}$.

Nutritional status and nutrient intake have significant effects on school performance and are related to cerebral function and memory capacity ${ }^{9}$. Malnutrition has serious long-term consequences ${ }^{10}$ and it may have negative impact on the cognitive development of schoolchildren ${ }^{11,12}$, who demonstrate a lower level of learning and development when compared to other students with adequate nutrient intake ${ }^{13}$.

Likewise, overweight, in addition to being a risk factor for health, is related to growth disorders, leading to difficulties in motor performance, low school performance and attention deficit ${ }^{14}$. One of the factors that contributes to overweight is the early introduction of ultraprocessed foods in the diet, which negatively affect health, since these foods are rich in fat, sugar, sodium and they have high energy density ${ }^{15}$. The imbalance of nutritional intake is one of the possible mechanisms for an association between overweight and school performance, since both excess and nutrient deficiency can cause changes in cerebral functions. The deficits of some specific nutrients, such as iron, can cause difficult concentration on studies ${ }^{16}$, and the psychosocial factors involved, such as low selfesteem, leading to absenteeism and consequent worsening in school performance ${ }^{17}$.

In addition, parents' participation in children's school life may be an important factor that helps to boost the students' performance18, because when there are stimulus and motivation in family environment, there is also a better chance for the students to be more involved in classroom activities ${ }^{19}$.
Thus, the present study aimed to analyze the relationship between dietary intake and nutritional status with school performance in a sample of public schools in a city of Rio Grande do Sul, Brazil.

\section{METHODS}

This is an observational, quantitative and crosssectional study carried out with schoolchildren enrolled in the 4th year of elementary school from ten public schools in one city in Rio Grande do Sul, Brazil. The sample was for convenience, composed of schoolchildren of both sexes, aged between 9 and 11 years old.

Data were collected from September to December 2016. Participants in the study were those who signed the Term of Assent and whose parents or guardians signed the Informed Consent Term (TCLE). Students who refused to complete some stage of the survey and those whose parents did not fill or partially completed the instruments used for data collection were excluded from the study. In a universe of 176 students, 134 participated in the study. The project was approved by the Ethics in Research Committee (COEP) of the University of Vale do Taquari - Univates, according to Resolution CNS 466/2012, under number $1,708,395$.

For weight measurement, a Plenna ${ }^{\circledR}$ brand digital scale was used, with an accuracy of 100 grams and a maximum capacity of $150 \mathrm{~kg}$. The student was placed in an orthostatic position (upright posture, feet together and with upper limbs extended along the body), barefoot and with the least possible clothing, being positioned in the center of the equipment. The height was measured using a Sanny Profissional ${ }^{\circledR}$ brand portable stadiometer with a precision of $0.1 \mathrm{~cm}$ and a maximum extension of two meters, fixed to the wall. The student was barefoot, leaning against the stadiometer, with his head held high and unprotected, staring at a fixed point at eye leve ${ }^{20}$.

Age was obtained from the date of birth informed by the school board. To evaluate the nutritional status, the anthropometric index Body Mass Index (BMI) by age and sex was used. Their values were expressed in z-score, as recommended by the World Health Organization ${ }^{21}$. The diagnosis of nutritional status was performed using WHO AnthroPlus ${ }^{\circledR}$ software, version 1.0.4 ${ }^{22}$.

For the analysis of the food consumption of schoolchildren, the Food Recall was used, carried out in 3 non-consecutive days, one of the evaluations referring to the weekend and the other two being performed on weekdays. Reminders were applied by the researcher during a previously scheduled interview and food images were used so that each student could indicate with greater precision the amount consumed, reducing the chances of errors in the portions reports ${ }^{23}$.

The obtained data were calculated using the software Dietwin $\AA$, version 2969, year 2008. Through this, the average of daily consumption of energy, carbohydrate, lipid, protein, calcium, iron and zinc was verified for further comparison with the Dietary Reference Intakes (DRIs) recommended values ${ }^{24}$. Through the information of the searched students, it was possible to 
calculate the average consumption of ultraprocessed foodstuffs in percentage of calories in comparison to the total energetic value. The definition of ultraprocessed foods was performed according to the Food Guide for Brazilian Population ${ }^{25}$.

Verification of school performance was done based on 2016 report cards. According to the school standard, students were evaluated through concepts according to the school performance level in the areas of languages, mathematics, humanities and natural sciences, and the possible results in each area are exemplified in Chart 1. In order to make it possible to analyze the average school performance in the school year, the concepts were replaced by grades, considering the highest value equivalent to each concept (Chart 1).

\begin{tabular}{|lcc|}
\hline Concept & Lowest equivalent grade & Highest equivalent grade \\
Insufficient & 0.00 & 5.00 \\
Regular & 5.10 & 6.00 \\
Good & 6.10 & 7.50 \\
Very good & 7.51 & 9.00 \\
Excellent & 9.10 & 10.00 \\
\hline
\end{tabular}

Chart 1: School concepts and their equivalent grades

Source: authors, 2017

In this way, it became possible to calculate the quarterly arithmetic average per student, including the sum of the four evaluated areas. After obtaining the three quarterly averages, the same procedure was performed in order to calculate the final average school performance in the year. For statistical analysis purposes, annual school performance averages were categorized again into concepts.

Data on the parents' marital status have been obtained through a structured questionnaire, filled out by the parents of the students, which was categorized into five variables (single, married, separated / divorced, widowed or other).

The data has been analyzed in the Statistical Package for the Social Sciences (SPSS), version 22.0. The level of significance was set at $5 \%(\mathrm{p}<0.05)$. Exact Fischer and t-student tests were used, correlation analyzes were also performed, and non-parametric Kruskal-Wallis and MannWhitney statistical tests were applied.

\section{RESULTS}

The students' age average was $10.2 \pm 0.5$ years, in which $50 \%(\mathrm{n}=67)$ were female. Regarding nutritional status, $59.7 \%(\mathrm{n}=80)$ of the sample presented a diagnosis of eutrophy, $18.7 \%(n=25)$ of overweight, $15.6 \%(n=21)$ of obesity and $6,0 \%(n=8)$ were underweight. There was no significant difference in age between boys and girls $(p=0.291)$, nor significant association between sexes and nutritional status $(\mathrm{p}=0.408)$.

It was observed that students had an average calories consumption of $1430.9 \pm 340.8$ per day and the daily calcium and iron intake was significantly lower than the recommended intake $(p=0.000)$. For the other nutrients, there was no significant difference to the recommendation (Table 1).

Table 1: Comparison of food consumption and reference values of DRIs (2011)

\begin{tabular}{lcccc}
\hline Food consumption & Reference values & Average & Standart Deviation & $\mathbf{p}$ \\
\hline Carbohydrate $(\%)$ & $45 \%$ a 65 & $51.28 \%$ & $7.34 \%$ & $\mathrm{NS}$ \\
Protein $(\%)$ & $10 \%$ a 30 & $16.73 \%$ & $3.87 \%$ & $\mathrm{NS}$ \\
Lipids $(\%)$ & $25 \%$ a 35 & $31.97 \%$ & $6.03 \%$ & $\mathrm{NS}$ \\
Calcium $(\mathrm{mg})$ & 1300 & 384.10 & 232.76 & $\mathrm{p} \leq 0.001$ \\
Zinc $(\mathrm{mg})$ & 8 & 7.68 & 3.90 & 0.348 \\
Iron $(\mathrm{mg})$ & 8 & 6.92 & 2.54 & $\mathrm{p} \leq 0.001$ \\
\hline
\end{tabular}

Legend: Student's t-test. NS - not significant.

It was observed that obese schoolchildren consume significantly more lipids $(\mathrm{p}=0.026)$ and calories $(\mathrm{p}=$ 0.003 ) in comparison to the other students. The other nutrients did not present significant differences when compared to the nutritional status classification (Table 2).

Ultraprocessed food represents $35.50 \pm 13.76 \%$ of the total calories ingested. There was a positive correlation between the consumption of this food and the amount of calories $(p=0.022)$ and the inverse correlation with zinc consumption $(\mathrm{p}=0.007)$ (Table 3$)$.

School performance with a regular concept was verified in $5.2 \%(\mathrm{n}=7)$ of the studied population, good in $33.6 \%(n=45)$, very good in $41.8 \%(n=56)$, excellent in 19 , $4 \%(n=26)$ and none of the students had insufficient school performance. There was no significant difference between food intake and school performance classifications (Table 4).

It was verified that there was no significant association between school performance and nutritional status $(p=0.532)$. Regarding the parents marital status, it was observed that good academic performance was significantly associated with the separated parents, and the excellent school performance was related to married parents $(\mathrm{p}=0.038)$ (Table 5). 
Table 2: Association between food consumption variables and nutritional status classifications

\begin{tabular}{|c|c|c|c|c|c|}
\hline Food consumption & Nutritional Status & $\mathbf{N}$ & Average & Standart Devation & $\mathbf{p}$ \\
\hline \multirow[t]{4}{*}{ Carbohydrate (\%) } & Underweight & 8 & 52.7 & 5.8 & 0.056 \\
\hline & Eutrophia & 80 & 52.5 & 7.3 & \\
\hline & Overweight & 25 & 50.4 & 6.9 & \\
\hline & Obesity & 21 & 47.2 & 7.4 & \\
\hline \multirow[t]{4}{*}{ Protein (\%) } & Underweight & 8 & 16.0 & 2.2 & 0.968 \\
\hline & Eutrophia & 80 & 16.7 & 4.0 & \\
\hline & Overweight & 25 & 16.6 & 3.6 & \\
\hline & Obesity & 21 & 17.2 & 4.2 & \\
\hline \multirow[t]{4}{*}{ Lipid (\%) } & Underweight & 8 & 31.4 & 6.1 & 0.026 \\
\hline & Eutrophia & 80 & 30.7 & 5.4 & \\
\hline & Overweight & 25 & 33.0 & 6.5 & \\
\hline & Obesity & 21 & 35.6 & 6.5 & \\
\hline \multirow[t]{4}{*}{ Calcium (mg) } & Underweight & 8 & 377.1 & 357.4 & 0,326 \\
\hline & Eutrophia & 80 & 370.4 & 226.0 & \\
\hline & Overweight & 25 & 373.3 & 229.3 & \\
\hline & Obesity & 21 & 451.7 & 211.9 & \\
\hline \multirow[t]{4}{*}{ Iron (mg) } & Underweight & 8 & 7.2 & 3.8 & 0.135 \\
\hline & Eutrophia & 80 & 6.6 & 2.5 & \\
\hline & Overweight & 25 & 6.8 & 2.0 & \\
\hline & Obesity & 21 & 8.0 & 2.3 & \\
\hline \multirow[t]{4}{*}{ Zinc (mg) } & Underweight & 8 & 7.2 & 3.9 & 0.446 \\
\hline & Eutrophia & 80 & 7.6 & 4.2 & \\
\hline & Overweight & 25 & 7.2 & 3.0 & \\
\hline & Obesity & 21 & 8.7 & 3.7 & \\
\hline \multirow[t]{4}{*}{ Ultraprocessed (\%) } & Underweight & 8 & 35.52 & 15.85 & 0.879 \\
\hline & Eutrophia & 80 & 35.91 & 13.44 & \\
\hline & Overweight & 25 & 33.75 & 12.97 & \\
\hline & Obesity & 21 & 36.01 & 15.84 & \\
\hline \multirow[t]{4}{*}{ Total calories } & Underweight & 8 & 1296.7 & 429.1 & 0.003 \\
\hline & Eutrophia & 80 & 1378.0 & 302.8 & \\
\hline & Overweight & 25 & 1436.9 & 371.7 & \\
\hline & Obesity & 21 & 1676.6 & 313.4 & \\
\hline
\end{tabular}

Non-parametric Kruskal-Wallis test.

Table 3: Correlation of the variables calcium, iron, zinc and calories with ultraprocessed food

\begin{tabular}{lcc}
\hline Food Consumption & Ultraprocessed food & p \\
\hline & $\mathrm{R}$ & \\
Calcium $(\mathrm{mg})$ & -0.042 & 0.627 \\
Iron $(\mathrm{mg})$ & -0.124 & 0.154 \\
Zinc $(\mathrm{mg})$ & -0.233 & 0.007 \\
Calories & 0.197 & 0.022 \\
\hline
\end{tabular}

Correlation analysis 
Table 4: Association between food consumption variables and school performance classifications

\begin{tabular}{|c|c|c|c|c|c|}
\hline Food consumption & Concept & $\mathbf{N}$ & Average & Standart Deviation & p \\
\hline \multirow[t]{4}{*}{ Carbohydrate (\%) } & Regular & 7 & 47.2 & 8.9 & 0.330 \\
\hline & Good & 45 & 52.2 & 8.6 & \\
\hline & Very Good & 56 & 51.3 & 6.0 & \\
\hline & Excellent & 26 & 50.7 & 7.0 & \\
\hline \multirow[t]{4}{*}{ Protein (\%) } & Regular & 7 & 15.3 & 3.9 & 0.253 \\
\hline & Good & 45 & 16.0 & 3.3 & \\
\hline & Very Good & 56 & 17.4 & 4.2 & \\
\hline & Excellent & 26 & 16.9 & 4.0 & \\
\hline \multirow[t]{4}{*}{ Lipids (\%) } & Regular & 7 & 37.5 & 6.9 & 0.109 \\
\hline & Good & 45 & 31.8 & 7.1 & \\
\hline & Very Good & 56 & 31.2 & 5.0 & \\
\hline & Excellent & 26 & 32.4 & 5.2 & \\
\hline \multirow[t]{4}{*}{ Calcium (mg) } & Regular & 7 & 409.7 & 218.2 & 0.919 \\
\hline & Good & 45 & 387.5 & 235.3 & \\
\hline & Very Good & 56 & 366.2 & 220.2 & \\
\hline & Excellent & 26 & 409.9 & 266.6 & \\
\hline \multirow[t]{4}{*}{ Iron (mg) } & Regular & 7 & 6.6 & 1.8 & 0.914 \\
\hline & Good & 45 & 7.1 & 2.8 & \\
\hline & Very Good & 56 & 6.7 & 2.2 & \\
\hline & Excellent & 26 & 7.2 & 3.0 & \\
\hline \multirow[t]{4}{*}{ Zinc (mg) } & Regular & 7 & 5.6 & 4.0 & 0.230 \\
\hline & Good & 45 & 7.8 & 3.9 & \\
\hline & Very Good & 56 & 8.0 & 3.9 & \\
\hline & Excellent & 26 & 7.3 & 3.9 & \\
\hline \multirow[t]{4}{*}{ Ultraprocessed (\%) } & Regular & 7 & 36.31 & 16.07 & 0.406 \\
\hline & Good & 45 & 38.39 & 14.66 & \\
\hline & Very Good & 56 & 33.09 & 13.11 & \\
\hline & Excellent & 26 & 35.48 & 12.66 & \\
\hline \multirow[t]{4}{*}{ Calories } & Regular & 7 & 1597.4 & 394.1 & 0.052 \\
\hline & Good & 45 & 1459.9 & 383.6 & \\
\hline & Very Good & 56 & 1354.9 & 306.8 & \\
\hline & Excellent & 26 & 1499.7 & 295.8 & \\
\hline
\end{tabular}

Non-parametric Kruskal-Wallis test.

Table 5: Association between food consumption variables and school performance classifications

\begin{tabular}{lllccccccccc}
\hline & \multicolumn{1}{c}{ School Performance } & & & \\
& & \multicolumn{1}{c}{ Regular } & \multicolumn{2}{c}{ Good } & Very good & Excelent & p \\
\hline \multirow{3}{*}{ Nutricional Status } & $\mathrm{n}$ & $\%$ & $\mathrm{n}$ & $\%$ & $\mathrm{~N}$ & $\%$ & $\mathrm{n}$ & $\%$ & \\
& Underweight & - & - & 3 & 37.5 & 2 & 25.0 & 3 & 37.5 & 0.532 \\
& Eutrophia & 3 & 3.8 & 28 & 35.0 & 32 & 40.0 & 17 & 21.3 & \\
& Overweight & 1 & 4.0 & 7 & 28.0 & 14 & 56.0 & 3 & 12.0 & \\
& Obesity & 3 & 14.3 & 7 & 33.3 & 8 & 38.1 & 3 & 14.3 & \\
\multirow{5}{*}{ Parents Marital Status } & Single & - & - & 5 & 27.8 & 11 & 61.1 & 2 & 11.1 & 0.038 \\
& Married & 7 & 7.4 & 27 & 28.7 & 37 & 39.4 & 23 & 24.5 & \\
& Separated & - & - & 13 & 65.0 & 6 & 30.0 & 1 & 5.0 & \\
& Widow & - & - & - & - & 2 & 100.0 & - & - & \\
\hline
\end{tabular}

Fischer's exact test 


\section{DISCUSSION}

The nutritional profile of the studied population presented higher indexes of overweight and obesity than malnutrition. The National School Health Survey $(\mathrm{PENSE})^{26}$, carried out among students aged 13 to 17 years old who were regularly attending public and private schools throughout the National Territory, observed a low weight in $3.1 \%$ of schoolchildren, while overweight was found in $23.7 \%$ of cases and obesity in $7.8 \%$. The values found in $\mathrm{PENSE}^{26}$ showed little variation between the female and the male sex, corroborating the data from this study, where no significant difference in nutritional status between boys and girls was found.

Souza et al..$^{27}$, who evaluated children and adolescents between 4 and 19 years old in schools in a city in the state of Rio Grande do Sul, found similar numbers, being $1.9 \%$ underweight, $18.9 \%$ overweight and $11.4 \%$ of obesity, the highest proportion of overweight was found among girls and the highest proportion of obesity among boys. Similar results were also observed in adolescents between 10 and 15 years old in the state of Paraná, where the observed percentage of overweight was $17.53 \%$, obesity $13.64 \%$, and low weight only among females in $3,06 \%$ of cases $^{28}$.

The nutritional transition of the Brazilian population was verified in the Family Budgets Survey (POF), which observed the increase in the prevalence of obesity and reduction of low weight in the population between 10 and 19 years old, in which it was observed, in 2002-200329, $15.1 \%$ of boys with overweight and $3.0 \%$ with obesity, among the girls the result was $16.7 \%$ of overweight and $4.11 \%$ of obesity. In $2008-2009^{30}$ there was an increase in both overweight and obesity, with $19.4 \%$ of overweight and $4.0 \%$ of obesity among boys, while among girls it was observed $21.7 \%$ of overweight and $5.9 \%$ of obesity. In conjunction with the increase in the prevalence of overweight, there was a reduction in cases of malnutrition. In $2002-2003^{29}$, boys presented $4.3 \%$ and girls $5.3 \%$ of weight deficiency. In $2008-2009^{30}$, these values decreased to $3.0 \%$ among boys and $3.7 \%$ among girls. The reduction of low weight cases and greater number of people with overweight and obesity, which characterizes the nutritional transition of the population, was also verified in the present study.

The increased prevalence of overweight and obesity is a reflection of excessive energy consumption, in conjunction with significant nutritional deficiencies in terms of micronutrients ${ }^{2}$. Nutritional deficiencies were observed in this study, since calcium intake was far below the limits recommended by DRIs ${ }^{24}$, as well as a study carried out in São Paulo by Assumpção et al. ${ }^{31}$, which verified calcium deficiency, with a consumption average of of $618.2 \mathrm{mg}$ per day in a sample of 10-19 year-old teenagers. In the study of Ribas et al. ${ }^{32}$ carried out in Paraná among 8-12 year-old schoolchildren, the observed average intake of calcium was $552.19 \mathrm{mg}$ among boys and $475.54 \mathrm{mg}$ among girls. When evaluating the food intake of Brazilian adolescents between 12 and 13 years old, Souza et al. ${ }^{33}$ verified that calcium is one of the micronutrients that presents a higher inadequate prevalence, reaching more than $95 \%$ of deficiency among
12-17 year-old teeenagers of public schools throughout the National Territory. Over $90 \%$ of 7-9 year old chidren who participated in the Albuquerque survey et al. ${ }^{34}$ in Ceará showed insufficient consumption of milk and dairy products, which are important sources of calcium in the diet.

Calcium is an essential nutrient for the body, which acts on maintaining bone mass, as well as preventing fractures and osteoporosis throughout life $\mathrm{e}^{31}$, and may also be related to school performance ${ }^{35}$. Adolescence is considered a critical period, since in this period of life there is the peak bone mass, where more than half of the skeleton is established. The deficiency of this nutrient in the studied age group becomes very worrying, since it is a phase of transition between childhood and adolescence, and the insufficient consumption of calcium at this moment can cause irreversible consequences for adult life $^{36}$. The inadequate consumption of iron in the sample of the studied population was also verified, a similar result to the study carried out in Maranhão by Pereira et $a l .{ }^{37}$, where they have found that $23.1 \%$ of the sample of adolescents between 10 and 19 years old consumed iron under the recommended amount and Souza et al..$^{33}$, who evaluated adolescents between 12 and 17 years of age in the National Territory and found innapropriated values of iron in $0.6 \%$ of boys and $2.5 \%$ of girls.

The reduction of body's iron storage may be related to stature disabiities, malnutrition or obesity in varying degrees $^{38}$, impairment of the immune system, difficulty in concentration and reduction of physical capacity ${ }^{39,40}$. After long periods of iron negative assessment, deficiency may lead to iron deficiency anemia, but even before anemia manifests itself, mild iron deficiency in the body can cause adverse effects on development ${ }^{38,39}$. Iron content in feed may be related to the increase in consumption of ultraprocessed foods, as verified by Louzada et al ${ }^{41}$, who observed that the participation of these foods in the diet was inversely and significantly associated with the consumption of iron, evidencing the disadvantage of ultraprocessed food, which may contribute to the development of nutritional deficiencies.

The dietary intake of zinc and macronutrients (carbohydrates, proteins and lipids) was in accordance with the values recommended by DRIs ${ }^{24}$. In the study by Souza et al. ${ }^{33}$, with Brazilian adolescents between 12 and 17 years old, the percentage of macronutrients and zinc was also in agreement with the reference values, differing from the result found by Vaz-Tostes et al. ${ }^{42}$, who performed a research in Espírito Santo, in which the adequacy of macronutrient consumption was observed, however, the dietary intake of zinc was inadequate among 2-6 year-old children, reaching $4.33 \mathrm{mg}$ of daily intake.

This mineral plays a very important role in children's and teenagers' health, acting directly on physical growth, sexual development, immune system and cognitive ability. Zinc deficiency present in early adolescence may slow the growth and affect learning ability. Therefore, it is necessary to evaluate the food consumption in these stages of life, to avoid losses due to its deficiency. It is important to be aware of this age group because, due to the growth rates, zinc rates needs may be higher in this period ${ }^{43,44}$. 
It was found that obese schoolchildren consumed significantly more lipids and total calories than the others. A study carried out in Ceará, among 7-9 year-old students, has found different results, since there were no significant differences in the food consumption of students with obesity. However, the sample evaluated showed inadequate consumption of some food groups (fruits, vegetables and milk and dairy products), besides the high frequency of physical inactivity and sedentary habits in this population, which may be related to the frequency of obesity found at that study ${ }^{34}$.

In this study, the impact of physical activity on nutritional status was not considered, but regular exercise practice may be effective in improving childhood obesity indicators $^{45}$, and when combined with healthy diet, may help to reduce psychological problems caused by discrimination for being overweight, which can cause depression and even social isolation ${ }^{46}$.

Studies conducted by Menêses et ll. $^{47}$, in the state of Tocantins, among children aged 5 to 10 years old, and Steil and Poll ${ }^{48}$, in the city of Candelária, RS, with students between 9 and 11 years old, did not observe differences of food consumption among nutritional status classifications. The divergent results can be explained by the fact that obesity is a multifactorial disease ${ }^{49}$, which transcends the results of caloric intake, and may be related not only to food consumption but also to breastfeeding early termination, with inadequate introduction of complementary feeding ${ }^{2}$, family environment, genetic, socioeconomic factors and regular practice of physical activity ${ }^{50}$.

In the sample of the studied population, more than a third of the energy value came from ultraprocessed food. It was observed the negative impact of this kind of intake on the nutritional quality of food, since the higher the consumption, the higher the caloric density found, evidencing its contribution to the number of overweight and obese children. This condition may cause serious health problems in children and adolescents, such as diabetes and cardiovascular diseases ${ }^{51}$.

There was also a correlation between the higher consumption of ultraprocessed food and the lower consumption of zinc. Similar data has been found by Louzada et al..$^{52}$, who evaluated the food consumption of 30 thousand Brazilians over 10 years old, and observed that the consumption of ultraprocessed food represented $30 \%$ of the total energy value, also confirming the association between its consumption and the prevalence of overweight and obesity in this population.

In Pelotas, RS, it was observed that children under 2 years old had $19.7 \%$ of consumption of ultraprocessed food in the diet, and children over 2 years old consumed $36.1 \%$, demonstrating the early introduction of this food in the children's diet and increasing its intake with aging progress ${ }^{15}$. When evaluating the food consumption of Brazilians over 10 years old, Louzada et al. ${ }^{41}$ observed that the intake of ultraprocessed food represented $21.5 \%$ of the total calories, while at the same time they also observed a relationship between the higher consumption of ultraprocessed food and lower zinc content in the diet.

Another study, conducted in Canada, has found higher values for consumption of ultraprocessed food, reaching $47.7 \%$ of the total energy value in general population. An inverse relationship was also observed between the consumption of this kind of food and the intake of zinc, reinforcing the findings in the present study $^{53}$

In United States, the consumption of ultraprocessed food is also high, reaching $57.9 \%$ of the energy value 54 . Through these studies, it can be observed lower consumption of ultraprocessed food in Brazil, when compared to other countries. One possible explanation for this fact is that in Brazil some types of ultraprocessed food have a high cost when compared to other groups, which suggests an economic advantage of replacing ultraprocessed food with homemade meals ${ }^{55}$.

There was no statistically significant association between dietary intake and nutritional status with school performance in the sample of the studied population. These results were also found in Rio de Janeiro, in a study carried out among students from 6th to 9th grade, in which there was also no association between diet and nutritional status with school grades ${ }^{9}$. Santana et al. ${ }^{56}$, in a systematic review, also did not observe sufficient evidence to support the direct link between food consumption and poor school performance of schoolchildren.

Different results were found in the study by Correa-Burrowset al. ${ }^{57}$, conducted in Chile, which evaluated the relationship between dietary intake and school performance in 16-year-old teenagers and showed that food with a high energy density were associated with a reduction in schoolchildren performance. In another study, carried out in the same place, with a 3 year-old population, it was also observed an association between feeding and school performance, where students who ate less healthy snacks were more likely to fail at school ${ }^{58}$. In Korea, Kim et al. ${ }^{35}$ evaluated 12-18 years-old adolescents and found that school achievement worsened in those who consumed ultraprocessed food more than 7 times a week.

In India, Rashmi et al. ${ }^{10}$ carried out a study with a population between 5 and 14 years-old and observed that malnutrition was a factor related to lower school performance. While Rossini et al..$^{59}$, in RS, verified the correlation between students' grades and nutritional status in schoolchildren aged 7 to 10 years old, observing that students with low weight presented higher marks than the others.

In some studies, it was observed that overweight and obesity were directly related to school performance. Phrashiah et $a l^{60}$ evaluated the relation between nutritional status and school performance in Kenya, and found out that the nutritional status classification in 1115 years old adolescents influenced school performance, mainly through low involvement of overweight student in the activities proposed in the classroom.

In the United States, Carey et al. ${ }^{61}$ found out that gain weight among children and adolescents aged 10 to 17 was associated with lower school performance, mainly promoting absenteeism, school year repetition and less involvement in school activities. The gain weight associated with lower school performance was also verified in a study conducted in the state of Minas Gerais, among 9-11 year-old students, enrolled on the 4th year of 
elementary public school ${ }^{16}$, and also in Portugal, in a study involving adolescents aged 12 to 18 years old ${ }^{62}$.

Identifying determinants of school performance is a complex task, since this process is influenced by several variables and is constantly changing, and may involve genetic, socioeconomic, environmental and behavioral factors ${ }^{60,63}$. The family structure is also a strong determinant factor of learning and school performance ${ }^{64}$, as verified in the results of the present study, where the children of married parents obtained higher educational achievement than the children of separated parents. Costa et $a l .{ }^{65}$, observed that the encouragement of parents in school routines improved students performance. Parents' paticipation in the children's school life is essential for the child's development. This importance stems from the interaction in the family environment and the quality of support in school tasks, by encouraging reading, stimulating oral and written expression, relevant aspects for cognitive development18. In the present study, the majority of the parents presented married marital status, an aspect that may have contributed to the fact that the studied population showed, for the most part, satisfactory school concepts.

It is also important to emphasize that there were no school concepts classified as insufficient, this fact may have contributed to the results found to be, in part, different from those verified in the literature. According to State Law No. 14,705, of June 25, 201566, every schoolchild with learning difficulties has the right to individual support, in a way that allows the student to improve their school performance. This student's support may also have helped to ensure that insufficient concepts were not verified. The study presented limitations, especially regarding the cross-sectional delineation of the research and the sample of students being from a small number of schools in a city in the state of RS. R24h, used to evaluate food consumption, may have had memory bias on the part of schoolchildren, and the results found reflected food consumption during the period in which it was performed, not observing dietary conditions throughout the school year.

Most of the evaluated schoolchildren presented a diagnosis of eutrophy, however, considerable percentages of overweight and obesity were verified. There was no statistically significant association between dietary intake and nutritional status with school performance. However, the marital status of the parents was associated with the performance of the students and inadequacies were observed in the dietary intake of calcium and iron in the studied age group, as well as the considerable participation of the ultraprocessed food in the diet.

The results of this research further emphasize the importance of adequate food since childhood, since it is one of the factors that act directly in the physical and cognitive development. In addition, it can be observed that family structure is one of the main conditions that contributes to school success. Studies such as this are extremely important in the field of public health, since they show the presence of overweight and obesity in childhood and adolescence, confirming the trend of change in the nutritional profile of the Brazilian population. Considering this scenario, the challenge is to develop efficient education and nutritional monitoring actions in order to control the nutritional transition observed in the population.

\section{REFERENCES}

1. Carvalho APLS. Importância da alimentação para melhorias na aprendizagem de crianças em unidades públicas de ensino: revisão integrativa. Rev Somma. 2016;2(2):74-83.

2. Carvalho CA, Fonsêca PCA, Priore SE, Franceschini SCC, Novaes JF. Consumo alimentar e adequação nutricional em crianças brasileiras: revisão sistemática. Rev Paul Pediatr. 2015;33(2):211-21. DOI: http://dx.doi.org/10.1016/j.rpped.2015.03.002

3. Villa JKD, Silva AR, Santos TSS, Ribeiro AQ, Pessoa MC, Sant'Ana LFR. Padrões alimentares de crianças e determinantes socioeconômicos, comportamentais e maternos. Rev Paul Pediatr. 2015;33(3):302-9. DOI: http://dx.doi.org/10.1016/j.rpped.2015.05.001

4. Teji K, Dessie Y, Assebe T, Abdo M. Anaemia and nutritional status of adolescent girls in Babile District, Eastern Ethiopia. Pan Afr Med J. 2016;24:62. DOI: http://dx.doi.org/10.11604/pamj.2016.24.62.6949

5. Araújo CG, Rosa SAM. Perfil socioeconômico e nutricional de escolares em uma instituição pública de ensino em Jaguaribara - CE. Rev APS. 2016;19(4):602-12.

6. Cadamuro SP, Oliveira DV, Bennemann RM, Silva ES, Antunes MD, Nascimento Júnior JRA, et al. Associação entre o nível socioeconômico e o consumo alimentar de crianças com idade escolar matriculadas na rede pública de ensino do município de Maringá-PR. Rev Cinergis. 2017;18(2):125-8. DOI: http://dx.doi.org/10.17058/cinergis.v18i2.8753

7. Santos LSF, Silva SCM, Ramos EMLS. Perfil nutricional de crianças de uma escola em Belém, PA. Rev Aten Saúde. 2017;15(51):69-74. DOI: http://dx.doi.org/10.13037/ras.vol15n51.4279

8. Pedraza DF, Silva FA, Melo NLS, Araujo EMN, Sousa CPC. Estado nutricional e hábitos alimentares de escolares de Campina Grande, Paraíba, Brasil. Ciênc Saúde Coletiva. 2017;22(2):469-77. DOI: http://dx.doi.org/10.1590/1413-81232017222.26252015

9. Moreira A, Benedetti NCM, Saron MLG, Neves AS, Souza EB. A influência do estado nutricional e da ingestão alimentar na aprendizagem escolar. Cad UniFOA. 2015;10(29):105-13. 
10. Rashmi MR, Shweta BM, Fathima FN, Agrawal T, Shah M, Sequeira R. Prevalence of Malnutrition and Relationship with Scholastic Performance among Primary and Secondary School Children in Two Select Private Schools in Bangalore Rural District. Indian J Community Med. 2015;40(2):97-102. DOI: http://dx.doi.org/10.4103/0970-0218.153871

11. Tandon PS, Tovar A, Jayasuriya AT, Welker E, Schober DJ, Copeland K, et al. The relationship between physical activity and diet and young children's cognitive development: A systematic review. Prev Med Rep. 2016;3:379-90. DOI: http://dx.doi.org/10.1016/j.pmedr.2016.04.003

12. Lam LG, Lawlis TR. Feeding the brain - The effects of micronutrient interventions on cognitive performance among school-aged children: a systematic review of randomized controlled trials. Clin Nutr. 2017;36(4):1007-14. DOI: http://dx.doi.org/10.1016/j.clnu.2016.06.013

13. Kim SH, Kim WK, Kang MH. Relationships between milk consumption and academic performance, learning motivation and strategy, and personality in Korean adolescents. Nutr Res Pract. 2016;10(2):198205. DOI: http://dx.doi.org/10.4162/nrp.2016.10.2.198

14. Rocha FF, Santos VAP, Contreira AR, Pizzo GC, Silva PN, Romero PVS, et al. Análise do desempenho motor e maturidade cognitiva de pré-escolares de Maringá (PR). Rev Saúde Pesquisa. 2016;9(3):50715. DOI: $10.17765 / 1983-1870.2016 v 9 n 3 p 507-515$

15. Karnopp EVN, Vaz JS, Schafer AA, Muniz LC, Souza RLV, Santos I, et al. Food consumption of children younger than 6 years according to the degree of food processing. J Pediatr. 2017;93(1):70-8. DOI: http://dx.doi.org/10.1016/j.jped.2016.04.007

16. Izidoro GSL, Santos JN, Oliveira TSC, Martins-Reis VO. A influência do estado nutricional no desempenho escolar. Rev CEFAC. 2014;16(5):1541-7. DOI: http://dx.doi.org/10.1590/1982-0216201417313

17. Afzal AS, Gortmaker S. The Relationship between Obesity and Cognitive Performance in Children: A Longitudinal Study. Child Obes. 2015;11(4):466-74. DOI: http://dx.doi.org/10.1089/chi.2014.0129

18. Alves AF, Lemos GC, Brito L, Martins AA, Almeida LS. Desempenho cognitivo na infância: a mãe e o meio urbano fazem a diferença. Psic Teor Pesq. 2016;32(3):e32317 DOI: http://dx.doi.org/10.1590/0102-3772e323217

19. Ribeiro R, Ciasca SM, Capelatto IV. Relação entre recursos familiares e desempenho escolar de alunos do $5^{\circ}$ ano do Ensino Fundamental de Escola Pública. Rev Psicopedagogia. 2016;33(101):164-74.

20. Brasil. Ministério da Saúde. Orientações para a coleta de dados antropométricos em serviços de saúde: Norma Técnica do Sistema de Vigilância Alimentar e Nutricional (SISVAN). Brasília: Ministério da Saúde, 2011.

21. World Health Organization (WHO). Growth reference 5-19 years. Development of a WHO growth reference for school-aged children and adolescents. WHO: 2007.

22. World Health Organization (WHO). Application tools: AnthroPlus software. WHO: 2007.

23. Monego E, Peixoto MR, Santiago R, Gil MF, Cordeiro MM, Campos MI, et al. Alimentos brasileiros e suas porções: um guia para avaliação do consumo alimentar. Rio de Janeiro: Rubio, 2013.

24. Institute of Medicine. Dietary Reference Intakes for Energy, Carbohydrate, Fat, Protein, Calcium, Iron and Zinc. [cited 2017 Feb 10] Available from: https://www.nal.usda.gov/sites/default/files/fnic_uploads/ recommended_intakes_individuals.pdf.

25. Brasil. Ministério da Saúde. Secretaria de Atenção à Saúde. Departamento de Atenção Básica. Guia alimentar para a população brasileira. 2 ed. Brasília: Ministério da Saúde, 2014.

26. Instituto Brasileiro de Geografia e Estatística (IBGE). Pesquisa Nacional de Saúde do Escolar 2015. [cited 2017 Sep 11] Available from: http://biblioteca.ibge.gov.br/visualizacao/livros/liv97870.pdf.

27. Souza LS, Santo ERC, Franceschi C, Ávila C, Centenaro S, Santos GS. Estado nutricional antropométrico e associação com pressão arterial em crianças e adolescentes: um estudo populacional. Sci Med. 2017;27(1):1-8. DOI: http://dx.doi.org/10.15448/1980-6108.2017.1.25592

28. Silva TKR, Camargo GA, Nuñez CEC, Silva CC, Ballard CR. Avaliação da alimentação escolar e estado nutricional de adolescentes. Rev Aten Saúde. 2017;15(51):62-8. DOI: 10.13037/ras.vol15n51.4278

29. Instituto Brasileiro de Geografia e Estatística (IBGE). Pesquisa de Orçamentos Familiares (POF) 20022003: Análise da disponibilidade domiciliar de alimentos e do estado nutricional no Brasil. [cited 2017 Sep 11] Available from: http://www.abeso.org.br/uploads/downloads/70/553a2408c2702.pdf.

30. Instituto Brasileiro de Geografia e Estatística (IBGE). Pesquisa de Orçamentos Familiares (POF) 20082009: Antropometria e estado nutricional de crianças, adolescentes e adultos no Brasil. [cited 2017 Sep 11] Available from: https://biblioteca.ibge.gov.br/visualizacao/livros/liv45419.pdf.

31. Assumpção D, Dias MRMG, Barros MBA, Fisberg RM, Barros Filho AA. Ingestão de cálcio por adolescentes: inquérito de saúde de base populacional. J Pediatr. 2016;92(3):251-9.

DOI: http://dx.doi.org/10.1016/j.jped.2015.09.004 
32. Ribas MR, Barroso Junior ML, Pereira TRA, Zonatto HA, Oliveira AG, Cordeiro HJ, et al. Perfil de macro e micro nutrientes na dieta de escolares do Ensino Fundamental. Rev Uniandrade. 2017;18(2):66-73. DOI: http://dx.doi.org/10.18024/1519-5694/revuniandrade.v18n2p66-73

33. Souza AM, Barufaldi LA, Abreu GA, Giannini DT, Oliveira CL, Santos MM, et al. ERICA: ingestão de macro e micronutrientes em adolescentes brasileiros. Rev Saúde Pública. 2016;50( Supl 1):5s. DOI: http://dx.doi.org/10.1590/S01518-8787.2016050006698

34. Albuquerque LP, Cavalcante ACM, Almeida PC, Carrapeiro MM. Relação da obesidade com o comportamento alimentar e o estilo de vida de escolares brasileiros. Nutr Clín Diet Hosp. 2016;36(1):1723. DOI: http://dx.doi.org/10.12873/361 parente

35. Kim SY, Sim S, Park B, Kong IG, Kim JH, Choi HG. Dietary Habits Are Associated With School Performance in Adolescents. Medicine. 2016;95(12):e3096 DOI: http://dx.doi.org/10.1097/MD.0000000000003096

36. Gordon CM, Zemel BS, Wren TA, Leonard MB, Bachrach LK, Rauch F, et al. The Determinants of Peak Bone Mass. J Pediatr. 2017;180:261-9. DOI: http://dx.doi.org/10.1016/j.jpeds.2016.09.056

37. Pereira CC, Barbosa JMA, Costa WJF, Costa Júnior ALR, Tonial SR, Martins MLB. Ingestão de calorias e nutrientes por adolescentes do estado do Maranhão. Rev Saúde Públ Santa Cat. 2016;9(1):25-36.

38. Niero CV, Morais FA, Madeira K, Serafim GS, Serafim AS, Simões PW. Crescimento ponderoestatural de pacientes de 0 a 16 anos com anemia ferropriva. Rev Inova Saúde. 2016;5(1):74-85. DOI: http://dx.doi.org/10.18616/is.v5i1.2372

39. Gomes JR, Pavanelli MF. Perfil das alterações hematológicas em crianças residentes na região de Campo Mourão - PR. Rev Iniciare. 2016;1(1):106-15.

40. Novaes TG, Gomes AT, Silveira KC, Magalães EIS, Souza CL, Pereira Netto M, et al. Prevalência e fatores associados à anemia em crianças de creches: uma análise hierarquizada. Rev Paul Pediatr. 2017;35(3):281-8. DOI: http://dx.doi.org/10.1590/1984 0462/;2017;35;3;00008

41. Louzada MLC, Martins APB, Canella DS, Baraldi LG, Levy RB, Claro RM, et al. Impacto de alimentos ultraprocessados sobre o teor de micronutrientes da dieta no Brasil. Rev Saúde Pública. 2015;49:45. DOI: http://dx.doi.org/10.1590/S0034-8910.2015049006211

42. Vaz-Tostes MG, Cardoso-Pires PC, Paula AH, Barros AA, Freitas FV, Pinheiro-Sant'Ana HM, et al. Estado nutricional relativo ao ferro, zinco e vitamina $A$ de pré-escolares inseridos em um programa de educação alimentar e nutricional. HU Rev. 2015;41(3-4):163-70.

43. Rodrigues BTC, Silva CPF, Ramalho AA. Deficiência do micronutriente zinco e crescimento linear em crianças: uma revisão integrativa. J Amazon Health Sci. 2015;1(1):36-47.

44. Pedraza DF, Sales MC, Menezes TN. Fatores associados ao crescimento linear de crianças socialmente vulneráveis do Estado da Paraíba, Brasil. Ciênc Saúde Coletiva. 2016;21(3):935-45. DOI: http://dx.doi.org/10.1590/1413-81232015213.20722014

45. Testa WL, Poeta LS, Duarte MFS. Exercício físico com atividades recreativas: uma alternativa para o tratamento da obesidade infantil. Rev Bras Obes Nutr Emagrecimento. 2017;11(62):49-55.

46. Carvalho ARM, Belém MO, Oda JY. Sobrepeso e obesidade em alunos de 6-10 anos de escola estadual de Umuarama/PR. Arq Ciên Saúde UNIPAR. 2017;21(1):3-12. DOI: https://doi.org/10.25110/arqsaude.v2i1.2017.6070

47. Menêses LEN, Silva NV, Labre MR, Castro JGD, Barbosa Filho JV, Pereira RJ. Consumo alimentar e estado nutricional de crianças em uma escola privada de Palmas, Tocantins. Rev Desafios. 2017;4(3):43-51. DOI: http://dx.doi.org/10.20873/uft.2359-3652.2017v4n3p43

48. Steil WF, Poll FA. Estado nutricional, práticas e conhecimentos alimentares em escolares. Rev Cinergis. 2017;18(3):226-32. DOI: http://dx.doi.org/10.17058/cinergis.v18i3.9385

49. Jardim JB, Souza IL. Obesidade infantil no Brasil: uma revisão integrativa. J Manag Prim Heal Care. 2017;8(1):66-90.

50. Mariz LS, Enders BC, Santos VEP, Tourinho FSV, Vieira CENK. Causas de obesidade infantojuvenil: reflexões segundo a teoria de Hannah Arendt. Texto Contexto Enferm. 2015;24(3):891-7. DOI: http://dx.doi.org/10.1590/0104-07072015002660014

51. Ribeiro BVS, Mendonça RG, Oliveira LL, Lima GS, Martins-Filho PRS, Moura NPR, et al. Anthropometry and lifestyle of children and adolescent in inland of northeastern Brazil. J Hum Growth Dev. 2017;27(2):140-7. DOI: http://dx.doi.org/10.7322/jhgd.119751

52. Louzada MLC, Baraldi LG, Steele EM, Martins AP, Canella DS, Moubarac JC, et al. Consumption of ultra-processed food and obesity in Brazilian adolescents and adults. Prev Med. 2015;81:9-15. DOI: http://dx.doi.org/10.1016/j.ypmed.2015.07.018 
53. Mourabac JC, Batal M, Louzada ML, Steele EM, Monteiro CA. Consumption of ultraprocessed foods predict diet quality in Canada. Appetite. 2017;108(1):512-20.

DOI: http://dx.doi.org/10.1016/j.appet.2016.11.006

54. Steele EM, Baraldi LG, Louzada MLC, Mourabac JC, Mozaffarian D, Monteiro CA. Ultra-processed foods and added sugars in the US diet: evidence from a nationally representative cross-sectional study. BMJ Open. 2016;6:e009892. DOI: http://dx.doi.org/10.1136/bmjopen-2015-009892

55. Claro RM, Maia EG, Costa BVL, Diniz DP. Preço dos alimentos no Brasil: prefira preparações culinárias a alimentos ultraprocessados. Cad Saúde Pública. 2016;32(8):e00104715 . DOI: http://dx.doi.org/10.1590/0102-311X00104715

56. Santana CCA, Hill JO, Azevedo LB, Gunnarsdottir T, Prado WL. The association between obesity and academic performance in youth: a systematic review. Obes Rev. 2017;18(10):1191-99. DOI: http://dx.doi.org/10.1111/obr.12582

57. Correa-Burrows P, Burrows R, Blanco E, Reyes M, Gahagan S. Nutritional quality of diet and academic performance in Chilean students. Bull World Health Organ. 2016;94(3):185-92. DOI: http://dx.doi.org/10.2471/BLT.15.161315

58. Correa-Burrows $P$, Burrows $R$, Orellana $Y$, Ivanovic $D$. The relationship between unhealthy snacking at school and academic outcomes: a population study in Chilean schoolchildren. Public Health Nutr. 2015;18(11):2022-30. DOI: http://dx.doi.org/10.1017/S1368980014002602

59. Rossini VG, Silva FM, Conde SR. Associação entre estado nutricional de crianças e rendimento escolar em uma amostra de escolas públicas de Encantado-RS. Rev UNINGÁ. 2016;47(1):17-23.

60. Phrashiah G, Peter C, Scolastica G. Nutritional Status and School Performance among Upper Primary Children in Selected Public Schools in Nairobi County, Kenya. Int J Health Sci Res. 2016;6(12):227-34.

61. Carey FR, Singh GK, Brown HS, Wilkinson AV. Educational outcomes associated with childhood obesity in the United States: cross-sectional results from the 2011-2012 National Survey of Children's Health. Int J Behav Nutr Phys Act. 2015;12(Suppl 1):S3. DOI: http://dx.doi.org/10.1186/1479-5868-12-S1-S3

62. Bastos F, Reis VM, Aranha AC, Garrido ND. Relação entre atividade física e desportiva, níveis de IMC, percepções de sucesso e rendimento escolar. J Motricidade. 2015;11(3):41-58. DOI: https://doi.org/10.6063/motricidade.3771

63. Santos CUS, Vianna PD, Bulhosa FA. O fracasso escolar entre estudantes do $6^{\circ}$ ano de Escolas Públicas Estaduais do Rio Grande, RS. Rev Ens Educ Ciênc Human. 2016;17(2):126-31.

64. Melo M. Família na escola: um vínculo condizente. Rev Cienc Salud, Educ Economia. 2017;1(11):60-73.

65. Costa K, Montiel JM, Bartholomeu D, Murgo CS, Campos NR. Percepção do suporte familiar e desempenho em leitura e escrita de crianças do Ensino Fundamental. Rev Psicopedag. 2016;33(101):154-63.

66. Estado do Rio Grande do Sul. Assembleia Legislativa. Lei no 14.705, de 25 de junho de 2015. Institui o Plano Estadual de Educação - PEE -, em cumprimento ao Plano Nacional de Educação - PNE -, aprovado pela Lei Federal n. ${ }^{\circ}$ 13.005, de 25 de junho de 2014. [cited 2017 Oct 09] Available from: http:// www.al.rs.gov.br/filerepository/repLegis/arquivos/LEl\%2014.705.pdf. 


\section{Resumo}

Introdução: A alimentação adequada durante a infância e a adolescência é extremamente importante, pois atua diretamente no desenvolvimento físico e cognitivo.

Objetivo: Verificar a relação entre o consumo alimentar e o estado nutricional com o rendimento escolar.

Método: Trata-se de um estudo observacional, quantitativo e transversal, realizado com 134 escolares com idades entre 9 e 11 anos. $O$ estado nutricional foi mensurado por meio do Índice de Massa Corporal por idade e gênero e a avaliação do consumo alimentar foi realizada através do Recordatório Alimentar de 3 dias. Para o conhecimento do rendimento escolar foram consultados os boletins do ano letivo de 2016 . Utilizouse um questionário para coletar dados referentes ao estado civil. Quanto ao estado nutricional, $59,7 \%$ dos escolares apresentaram eutrofia, $18,7 \%$ sobrepeso, $15,6 \%$ obesidade e $6,0 \%$ baixo peso.

Resultado: $O$ consumo de cálcio $(p=0,000)$ e ferro $(p=0,000)$ foram significativamente abaixo dos valores recomendados pela Dietary Reference Intakes. Os escolares com obesidade consumiram significativamente mais lipídios $(p=0,026)$ e calorias $(p=0,003)$ que os demais estudantes. A participação dos alimentos ultraprocessados representou $35,50 \%$ do valor energético total, observando-se correlação positiva entre o seu consumo e a quantidade de calorias da alimentação $(p=0,022)$ e correlação inversa com a ingestão de zinco $(p=0,007)$.

Conclusão: Não foi encontrada associação significativa entre o consumo alimentar e estado nutricional com o rendimento escolar, porém verificou-se que o estado civil dos pais apresentou associação com o desempenho dos estudantes, os filhos de pais casados tiveram um rendimento escolar superior aos filhos de pais separados.

Palavras-chave: consumo de alimentos, estado nutricional, eficiências nutricionais. 